\title{
PENGARUH PEMBERIAN TERAPI ANTIPSIKOTIK KOMBINASI TERHADAP TINGKAT DEPRESI PASIEN SKIZOFRENIA DI UPT PUSKESMAS TALUN KABUPATEN BLITAR
}

\author{
Sri Susilowati ${ }^{1}$, Martanty Aditya ${ }^{2)}$, Chresiani Destianita Yoedistira ${ }^{3)}$ \\ Program Studi Farmasi, Universitas Ma Chung \\ Email: 611810105@ student.machung.ac.id, martanty.aditya@machung.ac.id, \\ chresiani.destianita@machung.ac.id
}

\begin{abstract}
Abstrak
Skizofrenia merupakan penyakit psikiatrik kronis yang banyak menimbulkan masalah psikologis. Penatalaksanaannya dengan memberikan obat antipsikotik, diberikan dalam bentuk kombinasi. Penggunaan yang tidak tepat dapat menyebabkan terjadinya depresi dan kemungkinan mengalami efek samping terapi. Oleh karena itu perlu diukur efektifitas terapi yang diukur melalui tingkat depresi meliputi depresi ringan, sedang, berat, sangat berat.

Penelitian ini merupakan penelitian observasional dengan pendekatan cross sectional. Penelitian ini melibatkan 58 responden. Pengambilan data dilakukan dengan cara retrospektif, kemudian dilanjutkan dengan wawancara terstruktur oleh peneliti dibantu oleh asisten peneliti dengan instrument kuesioner Hamilton Depression Rating Scale (HDRS). Penelitian ini dilakukan pada penderita skizofrenia di UPT Puskesmas Talun Kabupaten Blitar pada bulan April-Juli 2020.

Dilakukan uji validitas dan reliabilitas pada kuesioner Hamilton Depression Rating Scale (HDRS). Pengaruh pemberian terapi antipsikotik kombinasi terhadap tingkat depresi dilakukan menggunakan uji Kruskal Wallis, dan didapatkan bahwa probabilitas > alpha (5\%), tidak terdapat perbedaan yang signifikan pada pemberian antipsikotik kombinasi, dan dilaporkan pula efek samping berupa ekstrapiramidal ringan, ekstrapiramidal berat dan tremor. Pada kombinasi I dilaporkan terjadi efek samping ektrapiramidal ringan 1 pasien, berat 1 pasien, tremor 1 pasien. Pada kombinasi II dilaporkan terjadi efek samping ekstrapiramidal ringan 2 pasien dan pada kombinasi III dilaporkan tidak ada kejadian efek samping.
\end{abstract}

Kata kunci: Antipsikotik Kombinasi, Skizofrenia, Tingkat Depresi

\section{PENDAHULUAN}

Skizofrenia adalah merupakan gangguan jiwa yang paling banyak terjadi, gejalanya ditandai dengan adanya distorsi realita, disorganisasi kepribadian yang parah, serta ketidakmampuan dari individu berinteraksi dengan kehidupan sehari-hari. Salah satu masalah kesehatan yaitu demensia, depresi, gangguan bipolar dan skizofrenia yang merupakan 10 masalah terbesar dimana menimbulkan disabilitas (World Health Organisation, 2016). Penyebab gangguan jiwa salah satunya adalah adanya tekanan yang berat dalam peristiwa hidup. Stres berasal dari lingkungan atau biologi ataupun bisa keduanya (Hawari, 2014).

Menurut World Health Organization (WHO, 2013) disebutkan bahwa skizofrenia merupakan penyakit gangguan jiwa yang menyerang hampir 24 juta masyarakat di seluruh dunia, lebih dari $50 \%$ penderita
Abstract
Schizophrenia is a chronic psychiatric disease that causes many psychological problems. Management by giving antipsychotic drugs, given in combination. Improper use can lead to depression and possible side effects of therapy. Therefore, it is necessary to measure the effectiveness of therapy as measured by the level of depression including mild, moderate, severe, and very severe depression.

This study is an observational study with a cross sectional approach. This study involved 58 respondents. Data collection was carried out in a retrospective manner, then followed by structured interviews by the researcher assisted by a research assistant with the Hamilton Depression Rating Scale (HDRS) questionnaire. This research was conducted on schizophrenic sufferers at the Talun Public Health Center, Blitar Regency in April-July 2020.

Validity and reliability were tested on the Hamilton Depression Rating Scale (HDRS) questionnaire. The effect of combination antipsychotic therapy on the level of depression was carried out using the Kruskal Wallis test, and it was found that the probability> alpha (5\%), there was no significant difference in the administration of combination antipsychotics, and side effects were also reported in the form of mild extrapyramidal, severe extrapyramidal and tremors. In combination I, mild extrapyramidal side effects were reported in 1 patient, severe in 1 patient, tremor in 1 patient. In combination II there were reported mild extrapyramidal side effects in 2 patients and in combination III there were no reported adverse events.

Keywords: Combination Antipsychotic, Schizophrenia, Depression Level

skizofrenia tidak mendapat pelayanan yang tepat dan $90 \%$ penderita skizofrenia yang tidak terawat berada di negara berkembang. Di Indonesia prevalensi tertinggi terdapat di Bali dan DI Yogyakarta dengan masing-masing 1,1 dan 10,4 per 1000 rumah tangga yang mengidap skizofrenia (Riskesdas, 2018).

Penatalaksanaan pengobatan pada pasien skizofrenia memperoleh terapi dalam jangka waktu yang panjang. Untuk menghasilkan perbaikan yang optimal dan untuk mencegah terjadinya kekambuhan yang parah. Obat skizofrenia yang biasa diresepkan adalah obat golongan antipsikotik. Obat golongan antipsikotik ini bekerja dengan mempengaruhi neurotransmitter dopamine serta mempengaruhi serotonin di dalam otak. Obat antipsikotik terdiri dari dua kelompok, yaitu antipsikotik generasi pertama dan antipsikotik generasi kedua. Pada penggunaan obat antipsikotik kombinasi dimungkinkan 
dapat menimbulkan efek samping, diantaranya ekstrapiramidal yaitu akathisia dengan konsumsi jangka panjang (Tjay \& Rahardja, 2015).

Seiring dengan memburuknya tingkat depresi, maka pada individu akan kehilangan minat terhadap banyak hal dan akhirnya individu dapat kehilangan minat terhadap makan, minum dan seks (Car, 2001). Selain itu terkait dengan aspek kognitif depresi, individu depresif memusatkan perhatian secara selektif pada kemungkinankemungkinan dan aspek-aspek buruk dalam hidup dan lingkungan. Hal ini kemudian mendorong individu depresif mengembangkan cara berfikir yang depresif, seperti memandang diri secara inferior, pesimis terhadap masa depan, merasa bersalah berlebihan dan pola-pola perilaku yang menghukum. Dalam depresi yang berat, distorsi kognitif ini mengarah pada membayangkan (ideasi) bunuh diri dan kadang bahkan pada percobaan bunuh diri (Rosenhan dan Seligman, 1989).

Studi pendahuluan di UPT Puskesmas Talun Kabupaten Blitar, terdapat 58 pasien skizofrenia yang berkunjung dan melakukuan pengobatan secara rutin dan berkala. Terapi yang diberikan adalah anti depresan golongan psikotropika. Salah satu kombinasi antipsikotik yang diresepkan kepada pasien skizofrenia adalah haloperidol, chlorpromazine dan triheksifenidil. Menurut Wicaksana (2000), pengobatan skizofrenia secara biologis dapat dilakukan dengan pemberian obat-obat seperti clozapine, risperidone, olanzepine, haloperidol. Obat-obat generasi kedua ini termasuk dalam golongan psikofarmaka yang bisa menetralisir gejala-gejala akut skizofrenia seperti tingkah laku kacau, gaduh gelisah, halusinasi pendengaran, inkoherensi, maupun menghilangkan gejala-gejala negatif (kronik) seperti autistik (pikiran penuh fantasi dan tidak terarah) dan gangguan dorongan kehendak.Pemberian bersamaan pada antipsikotik generasi pertama dan generasi kedua terjadi apabila pemberian antipsikotik generasi pertama atau generasi ke dua tidak memberikan efek. Dalam pelaksanannya terapi pada pasien skizofrenia dimungkinkan diberikan dalam bentuk kombinasi sehingga memungkinkan terjadinya interaksi dan efek samping. Misalnya efek ekstrapiramidal, tremor. Interaksi yang terjadi antara antikonvulsan dengan antipsikotika. Akibatnya perasaan lapar yang terus-menerus karena kedua obat ini merupakan depresan susunan saraf pusat, dapat terjadi depresi aditif dengan gejala mengantuk,pusing, hilang koordinasi motorik dan kewaspadaan mental.

Penelitian ini bertujuan untuk mengetahui efek samping yang terjadi pada penggunaan antipsikotik kombinasi pada pasien skizofrenia di UPT Puskesmas Talun Kabupaten Blitar dan untuk mengetahui perbedaan pengaruh pemberian terapi antipsikotik kombinasi terhadap tingkat depresi pada pasien skizofrenia di UPT Puskesmas Talun Kabupaten Blitar.

\section{Metode}

Rancangan penelitian pada penelitian ini merupakan penelitian observasional dengan pendekatan cross sectional. Pengambilan data dilakukan secara retrospektif kemudian dilanjutkan dengan wawancara terstruktur terkait tingkat depresi pasien skizofrenia yang menjalani pengobatan di UPT Puskesmas Talun Kabupaten Blitar pada tahun 2020. Kombinasi obat antipsikotik diperoleh dari resep, dianalisis terkait perbedaan pengaruh pemberian obat antipsikotik kombinasi dengan tingkat depresi dan dimungkinkan adanya efek pada penggunaan kombinasi antipsikotik dan wawancara kepada pasien maupun keluarga pasien yang disajikan dalam bentuk deskriptif. Penelitian ini dilakukan di wilayah UPT Puskesmas Talun Kabupaten Blitar. Penelitian ini dilaksanakan pada bulan Mei 2020 sampai dengan bulan Juli 2020 dengan kurun waktu pelaksanaan kurang lebih tiga bulan.

Populasi dalam penelitian ini adalah semua pasien skizofrenia di UPT Puskesmas Talun Kabupaten Blitar pada tahun 2020. Sampel dalam penelitian ini sama dengan populasi pasien skizofrenia yang diterapi dengan obat antipsikotik kombinasi. Pasien sebanyak 58 orang. Instrumen yang dilakukan dalam penelitian ini terdiri dari dua bagian. Bagian pertama berisi lembar pengumpul data yang berisi data pasien untuk mengetahui karakteristik pasien. Lembar kedua berisi kuesioner Hamilton Depression Rating Scale (HDRS) untuk mengukur tingkat depresi. Untuk melihat perbedaan pengaruh pemberian terapi antipsikotik kombinasi terhadap tingkat depresi pada pasien skizofrenia dilakukan uji KruskalWallis. Dalam proses analisis data ini peneliti menggunakan komputer program SPSS 23. 


\section{Hasil}

\section{Analisis Deskriptif}

Tabel 1. Analisis diskriptip Tingkat Depresi

\begin{tabular}{|c|c|c|c|c|c|c|c|}
\hline \multirow{2}{*}{ Tingkat Depresi } & \multicolumn{2}{|c|}{ Kelompok I* } & \multicolumn{2}{|c|}{ Kelompok II** } & \multicolumn{2}{|c|}{ Kelompok III**** } & \multirow{3}{*}{$\begin{array}{l}\text { Nilai/ } \\
\text { Skor } \\
<7\end{array}$} \\
\hline & Frek. & $\%$ & Frek. & $\%$ & Frek. & $\%$ & \\
\hline Normal & 3 & 15.8 & 6 & 27,3 & 1 & 5,9 & \\
\hline Depresi ringan & 4 & 21.1 & 5 & 22.7 & 1 & 5,9 & $8-13$ \\
\hline Depresi sedang & 3 & 15.8 & 2 & 9.1 & 6 & 35,3 & $14-18$ \\
\hline Depresi berat & 1 & 5,3 & 4 & 18.2 & 4 & 23,5 & $19-22$ \\
\hline $\begin{array}{c}\text { Depresi sangat } \\
\text { berat }\end{array}$ & 8 & 42,1 & 5 & 22,7 & 5 & 29,4 & $>23$ \\
\hline TOTAL & 19 & 100 & 22 & 100 & 17 & 100 & \\
\hline
\end{tabular}

Berdasarkan tabel di atas dapat diketahui bahwa dari 19 orang pasien skizofrenia kombinasi kelompok I, yaitu obat antipsikotik haloperidol, triheksiphenidil, chlorpromazin sebanyak 3 orang (15.8\%) tidak mengalami depresi, 4 orang $(21,1 \%)$ mengalami depresi ringan, 3 orang $(15,8 \%)$ mengalami depresi sedang, 1 orang $(5,3 \%)$ mengalami depresi berat dan 8 orang $(42,1 \%)$ mengalami depresi sangat berat.
Selanjutnya 17 orang pasien skizofrenia yang diberikan kombinasi kelompok III, kombinasi risperidon, chlorpromazine, triheksiphenidil sebanyak 1 orang $(5,9 \%)$ tidak mengalami depresi, 1 orang $(5,9 \%)$ mengalami depresi ringan, 6 orang $(35,3 \%)$ mengalami depresi sedang, 4 orang $(23,5 \%)$ mengalami depresi berat, dan 5 orang $(29,4 \%)$ mengalami depresi sangat berat.

\section{Tingkat Depresi dari Tiga Kelompok}

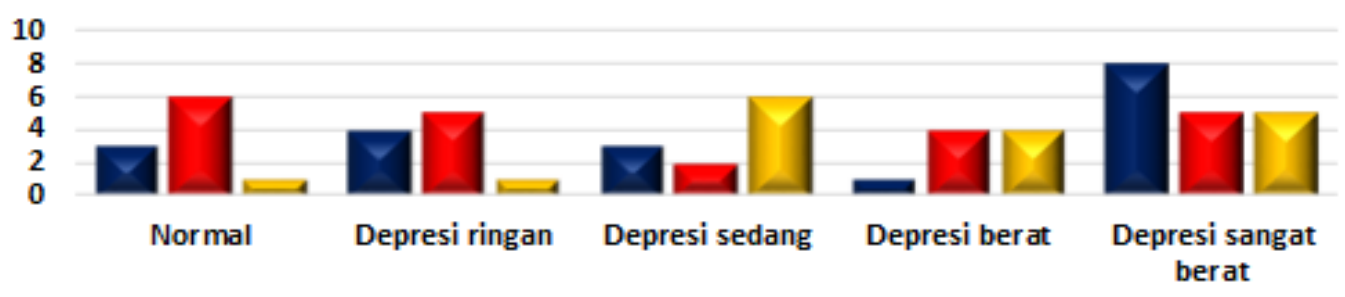

Kombin asi 1 haloperidol,triheksiphen idil,clorpromazin

Kombin asi 2 fluphenazine decanoat, haloperidol,clorpromazin

AKombin asi 3 resperidon, chlorpromazine, trih eksip hen idil

Gambar 1. Tingkat Depresi 
Efek Samping yang ditimbulkan pada Pemberian Terapi Antipsikotik Kombinasi

Tabel 2. Efek Samping yang ditimbulkan

\begin{tabular}{llll}
\hline Efek & Kombi & Kombi & Kombi \\
Samping & nasi & nasi & nasi \\
& I* & II** & III*** \\
& Jumla & Jumla & Jumla \\
& $\mathbf{h}(\%)$ & h (\%) & h( \%) \\
\hline Ekstrapir & $1(5,2)$ & $2(9,0)$ & - \\
amidal & & & \\
(EPS) & & & \\
ringan & & & \\
\hline Ekstrapir & $1(5,2)$ & - & \\
amdal & & & \\
(EPS) & & & \\
berat & & & \\
\hline Tremor & $1(5,2)$ & - & \\
\hline
\end{tabular}

Dari tabel diatas diketahui bahwa dari 58 responden yang menggunakan obat antipsikotik kombinasi pada kelompok I, II dan III, terdapat 5 responden yang mengalami efek samping. Tiga responden pada kelompok kombinasi I dan dua responden pada kelompok kombinasi II. Efek samping yang ditimbulkan berupa Ekstrapiramidal ringan, dengan gejala kaku - kaku di leher bagian atas dan bagian lengan tangan, namun masih bisa melakukan aktifitas. Gejala ini hanya terjadi beberapa jam saja. Satu responden pada kelompok kombinasi I mengalami Ekstrapiramidal berat. Gejala yang dialami berupa kekakuan di seluruh badan, sehingga tidak bisa melakukan aktifitas untuk keperluan dirinya sendiri. Berjalan seperti robot. Gejala ini berlangsung cukup lama yaitu 1-2 hari. Dan satu responden dari kelompok kombinasi I mengalami tremor. Gejala ini terjadi di lengan bagian bawah hingga telapak tangan. Gejala tremor ini hanya berlangsung beberapa saat dan terjadi setelah minum obat.

Perbedaan Pengaruh Pemberian Terapi Antipsikotik Kombinasi Terhadap Tingkat Depresi Pada Pasien Skizofrenia

Kriteria pada pengujian ini menyebutkan bahwa apabila probabilitas $\leq$ level of significance $($ alpha $=5 \%)$ maka $\mathrm{H}_{0}$ ditolak, sehingga dapat dinyatakan bahwa minimal ada satu pasang kelompok pasien skizofrenia yang memiliki tingkat depresi berbeda signifikan.

Hasil pengujian perbedaan pengaruh pemberian terapi antipsikotik kombinasi terhadap tingkat depresi pada pasien skizofrenia dapat dilihat melalui tabel berikut:
Tabel 3. Hasil Uji Kruskal Wallis

\begin{tabular}{ll}
\hline $\begin{array}{c}\text { Chi Square } \\
\text { Statistics }\end{array}$ & 2,642 \\
\hline Probabilitas & 0,267 \\
\hline
\end{tabular}

Tabel di atas menginformasikan bahwa pengujian perbedaan pengaruh pemberian terapi antipsikotik kombinasi terhadap tingkat depresi pada pasien skizofrenia menghasilkan statistik uji chi square sebesar 2,642 dengan probabilitas sebesar 0,267. Hal ini dapat diketahui bahwa probabilitas > alpha (5\%), sehingga Ho diterima. Oleh karena itu dapat dinyatakan bahwa tidak terdapat perbedaan yang signifikan perbedaan pengaruh pemberian terapi antipsikotik kombinasi terhadap tingkat depresi pada pasien skizofrenia.

\section{Pembahasan}

Responden pada penelitian ini adalah semua pasien skizofrenia di UPT Puskesmas Talun Kabupaten Blitar yang memperoleh pengobatan antipsikotik kombinasi pada kelompok I, kelompok II, dan kelompok III yang berusia 18 tahun sampai dengan 65 tahun dan telah melakukan pengobatan sedikitnya selama 4 bulan. Menunjukkan bahwa sebaran karakteritik responden merata pada kelompok kombinasi I, II maupun III atau tidak ada hubungan yang bermakna antara karakteristik responden dengan penggunaan obat antipsikotik kombinasi pada pasien skizifrenia. Pada dasarnya prevalensi antara laki-laki dan perempuan adalah hampir sama, tetapi onset penyakitnya lebih awal terjadi pada laki-laki (Fatemi, 2009). Hal ini disebabkan oleh beberapa faktor diantaranya karena kecenderungan yang lebih besar mendapatkan trauma kepala pada laki-laki dan adanya efek neuroprotektif dari hormon estrogen dan progesteron pada perempuan (Seeman, 2004). Pada umumnya hasil akhir pengobatan pasien skizofrenia perempuan lebih baik daripada hasil akhir pasien laki-laki (Kaplan, 2002).

Berdasarkan hasil uji validitas pada kuesioner, hasilnya dinyatakan valid dan mampu mengukur variabel yang diukurnya dan semua jenis pertanyaan pada kuesioner memiliki nilai nilai koefisien korelasi dengan skor total > nilai korelasi tabel. Dan pada pengujian reliabilitas kreteria pengujian menyatakan reliabel atau konsisten dalam mengukur variabel yang diukurnya, dan didapatkan hasil bahwa semua nilai Cronbach's Alpha > 0,6 sehingga pertanyaan pada kuesioner dinyatakan reliabel atau konsisten.

Pada hasil uji perbedaan pengaruh pemberian antipsikotik kombinasi terhadap tingkat depresi pada pasien skizifrenia menghasilkan bahwa tidak terdapat perbedaan yang signifikan. Uji menggunakan statistik Kruskal Wallis perbedaan pengaruh pemberian terapi antipsikotik kombinasi terhadap tingkat depresi pada pasien skizofrenia diperlihatkan pada tabel statistik uji chi square sebesar 1,323 dengan probabilitas sebesar 0,516. Hal ini dapat diketahui bahwa probabilitas > alpha (5\%) sehingga dikatakan Ho diterima. Artinya tidak terdapat perbedaan yang signifikan pada pemberian terapi antipsikotik kombinasi. di tiga kelompok yaitu kelompok I, kelompok II dan kelompok III terhadap tingkat depresi 
sangat berat pada pasien skizofrenia dimana 8 responden pada kelompok kombinasi I, 5 responden pada kelompok kombinasi II, dan 5 responden pada kelompok kombinasi III.

Depresi merupakan gangguan mental yang umumnya ditandai dengan perasaan depresi, kehilangan minat atau kesenangan, penurunan energi, perasaan bersalah atau merasa rendah diri, sulit tidur, nafsu makan berkurang, perasaan kelelahan dan kurang konsentrasi. Kondisi tersebut dapat menjadi kronis yang berulang dan secara substansial dapat mengganggu kemampuan individu dalam menjalankan tanggungjawab sehari- hari. Di tingkat yang paling parah, depresi dapat menyebabkan penderitanya melakukan bunuh diri (WHO, 2012).

Kelompok kombinasi I, haloperidol (HLP) triheksifenidil (THP) dan chlorpromazin (CPZ. Haloperidol (HLP) termasuk antagonis reseptor D2 paling kuat akan tetapi lemah terhadap efek sistem otonom, efek antikolinergik dan efek samping sedatif, sedangkan yang bekerja pada reseptor adrenergik $(\alpha 1)$, dopamin, kolinergik, muskarinik dan histaminergik (H1) juga memiliki efek sedatif cukup kuat untuk mengatasi gejala yaitu clorpromazin (Fujimaki et al.,2012).

Kombinasi obat antara chlorpromazin (CPZ) dan haloperidol (HLP) bertujuan memperkuat terapi antipsikotik untuk mengatasi efek sedatif dan gejala positif (Handayani et al., 2017). Mekanisme kerja haloperidol dan clorpromazin yaitu antagonis reseptor D2 dan D3 yang merupakan antipsikotik tipikal yang mampu mengatasi gejala positif seperti mendengar suara yang tidak nyata, melihat hal hal yang tidak nyata dan memiliki keyakinan aneh pada skizofrenia akan tetapi kurang efektif untuk mengatasi gejala negatif pada skizofrenia (Ren et al., 2013) Penggunaan kombinasi tipikal-atipikal perlu diperhatikan karena memungkinkan terjadinya efek ekstrapiramidal dan kemungkinan reseptor dopamin yang ada pada jalur nigrostriatal terduduki sehingga efek samping ekstrapiramidal lebih sering terjadi (Sinaga, 2007). Untuk mengatasinya maka digunakan trihexyphenidyl (THP) dengan dosis 3 kali $2 \mathrm{mg}$ per hari. Pemberian trihexyphenidil (THP) diberikan bersamaan dengan haloperidol (HLP) dapat menurunkan konsentrasi haloperidol (HLP) dalam serum, sehingga akan mengurangi efek terapeutik haloperidol (HLP). Haloperidol mengalami metabolisme menjadi bentuk inaktif di hati dengan melibatkan aktifitas enzim CYP 3A4. Obat antikolinergik merupakan inducers yang bersifat efektif terhadap enzim CYP 3A4, sehingga meningkatkan kerja enzim CYP 3A4 dalam memetabolisme haloperidol (HLP) menjadi inaktif. Meningkatnya konsentrasi haloperidol (HLP) dalam bentuk inaktif dapat menyebabkan penurunan efek farmakologi haloperidol (HLP) (Lacy, 2008). Ketika haloperidol (HLP) dikombinasikan dengan trihexyphenidil (THP), maka harus dilakukan penyesuaian dosis dan monitoring perkembangan gejala psikosis pasien. Jika terjadi peningkatan gejala psikosis maka sebaiknya pemberian trihexyphenidil (THP) dihentikan atau diganti dengan antikolinergik lain yang tidak mempunyai profil interaksi obat dengan haloperidol (HLP). Pada kelompok kombinasi ini dilaporkan ada 3 responden mengalami efek samping yaitu ekstrapiramidal dan tremor.
Pada kelompok kombinasi II, flupenazin decanoat - haloperidol (HLP) dan chlorpromazin (CPZ). Chlorpromazin dan haloperidol mengalami interaksi yaitu meningkatkan antidopaminergik yang dapat menimbulkan gejala ektrapiramidal simtom dan neuroleptic malignant syndrome. Untuk mengatasi interaksi tersebut maka diberikan fluphenazin decanoat. Fluphenazin decanoat ini merupakan golongan antipsikotik tipikal yaitu antidopaminergik yang bekerja sebagai antagonis reseptor dopamin dengan afinitas tinggi, sehingga tidak memerlukan penggunaan setiap hari sehingga bisa meningkatkan kepatuhan pengobatan pada pasien dan menurunkan kemungkinan terjadinya kekambuhan. Pada penggunaan flupenazin decanoat mengakibatkan peningkatan metabolisme dopamin pada otak dan membentuk radikal bebas dan Reactive Oxygen Species (ROS). Auto-oksidasi dopamin menyebabkan pembentukan neuromelamin dan quinon serta Reactive Oxygen Species (ROS). Oksidasi oleh dopamin oleh reaksi enzimatis yang dikatalisis oleh Mono Amine Oxidase (MAO) sehingga dapat menyebabkan pembentukan $\mathrm{H}_{2} \mathrm{O}_{2}$, deaminase metabolit membentuk asam 3,4 dihidroksibensoat dan asam homovanilat. Golongan fenotiazin memiliki efek pada sistim saraf pusat, otonom dan endokrin. Meskipun fungsi utama golongan ini memblokade reseptor D2, tetapi efek samping yang ditimbulkan dapat mempengaruhi $\alpha$ adrenoreseptor dan muskarinik, H1 histaminik dan reseptor 5-HT2.

Pemberian obat pada kombinasi kelompok III, risperidon-chlorpromazin - $\quad$ trihexyphenidil. Trihexyphenidil merupakan golongan antikolinergik penghambat asetilkolin yang bekerja sentral. Trihexyphenidil bersifat antagonis terhadap antipsikotik tipikal golongan fenotiazin (chlorpromazin dan trifluoperazin). Chlorpromazin dan trihexyphenidil mempunyai target kerja pada sistem saraf pusat, tetapi efek yang ditimbulkan bersifat antagonis. Efek trihexyphenidil pada sistim saraf pusat menyebabkan terjadinya gelisah, agitasi, delusi, halusi dan perubahan pikiran (Stokley,2009). Secara umum penggunaan obat antikolinergik tidak boleh melebihi waktu 3 bulan, tidak dianjurkan pemberian antikolinergik profilaksis karena dapat mempengaruhi penyerapan dari obat golongan antipsikotik, sehingga kadarnya dalam plasma menjadi rendah, sehingga dapat menghalangi manifestasi gejala psikopatologis yang dibutuhkan untuk penyesuaian dosis antipsikotik agar tercapai dosis efektif (Maslim,2007). Efek ekstrapiramidal yang ditimbulkan tidak hanya diatasi dengan pemberian antikolinergik, tetapi dapat diatasi dengan memperkecil dosis antipsikotik atau menggantikan dengan antipsikotik atipikal dengan efek samping ekstrapiramidal (EPS) lebih kecil seperti risperidon (Anonim,2009). Dengan pemberian risperidon dimana risperidon merupakan derivat dari benzisoxazole dengan afinitas terhadap reseptor serotonin 5-HT2 dan dopamin D2 dan beberapa afinitas terhadap reseptor alfaadregenik, histamin H2, dan dopamin D1. Risperidon memiliki afinitas lebih tinggi terhadap reseptor dopamin D2 daripada clozapin. Risperidon diindikasikan sebagai terapi skizofrenia baik untuk gejala negatif maupun gejala positif. Pada kelompok ini pasien mengalami perubahan 
berupa mulut kering, konstipasi, mengantuk dan responden menganggap sebagai hal yang biasa.

Dari hasil wawancara dilaporkan bahwa pada kelompok kombinasi III tidak terjadi adanya efek samping. Ini dikarenakan responden menganggap yang terjadi merupakan hal yang biasa. Yang dialami berupa mulut kering, sedikit mengantuk dan terkadang mengalami konstipasi.

\section{Kesimpulan}

Berdasarkan hasil penelitian yang telah dilakukan tentang Pengaruh Pemberian Terapi Antipsikotik Kombinasi Terhadap Tingkat Depresi pada Pasien Skizofrenia di UPT Puskesmas Talun Kabupaten Blitar, dapat disimpulkan bahwa:

1. Terdapat efek samping yang terjadi pada pemberian terapi antipsikotik kombinasi pada pasien skizofrenia. Efek samping yang ditimbulkan adalah tremor, ekstrapiramidal ringan dan ekstrapiramidal berat. Responden yang menggunakan antipsikotik kombinasi I terdapat 1 responden mengalami efek ekstrapiramidal berat, 1 responden mengalami efek ekstrapiramidal ringan dan 1 responden mengalami tremor. Pasien yang menggunakan antipsikotik kombinasi II terdapat 2 responden mengalami efek ekstrapiramidal ringan. Pasien yang menggunakan antipsikotik kombinasi III tidak melaporkan adanya efek samping, karena responden beranggapan bahwa mengantuk, mulut terasa kering dan konstipasi dianggap sebagai hal yang biasa.

2. Tidak terdapat perbedaan tingkat depresi yang signifikan pada pemberian terapi antipsikotik kombinasi pada pasien skizofrenia di UPT Puskesmas Talun Kabupaten Blitar. Ini terjadi pada tingkat depresi sangat berat. Didapatkan pada tingkat depresi sangat berat adalah 8 responden menggunakan antipsikotik kelompok kombinasi I, 5 responden menggunakan antipsikotik kelompok kombinasi II, dan 5 responden menggunakan obat antipsikotik kombinasi dari kelompok III.

\section{Saran}

Berikut ini dipaparkan bahwa saran dari hasil penelitian tentang pengaruh antara pemberian obat antipsikotik kombinasi dengan tingkat depresi pada pasien skizofrenia di UPT Puskesmas Talun Kabupaten Blitar :

1. Penelitian selanjutnya peneliti sarankan dilakukan di rumah sakit sehingga bisa mengkaji lebih dalam penggunaan antipsikotik kombinasi pada pasien skizofrenia, sehingga hasilnya dapat dipakai sebagai bahan perbandingan dengan hasil penelitian ini.

2. Selanjutnya penelitian tentang interaksi yang ditimbulkan pada penggunaan obat antipsikotik kombinasi yang terjadi pada pasien skizofrenia.

3. Penelitian selanjutnya diharapkan meneliti tingkat depresi pada remaja dengan menggunakan metode kwantitatif deskriptif.

\section{Daftar Pustaka}

Azwar, Saifuddin. 2010. Reliabilitas dan Validitas. Yogyakarta: Pustaka Pelajar.
Azwar, S.2010. Sikap Manusia Teori dan Pengukurannya. Yogyakarta: Pustaka Pelajar.

Benhard,R.(2007). Skizofrenia dan diagnosis banding. Jakarta:FK UI.

Data Riset Kesehatan Dasar (2018). Riset Kesehatan Dasar Tahun 2018. Depkes RI.

Dahlan, M. Sopiyudin. (2014) Statistik untuk Kedokteran dan Kesehatan . Jakarta: Epidemiolpgi Indonesia.

Dipiro, J., Wells, B., Schwinghammer, T., \& Dipiro, a, C. (2012).

Pharmacotherapy Handbook, Ninth Edit. Inggris: McGraw-Hill Edication Companies.

Hawari, Dadang. (2013). Manajemen Stres,Cemas, dan Depresi. Jakarta: Fakultas Kedokteran Universitas Indonesia

Katzung, B. (2012). Farmakologi Dasar dan Klinik (10th ed.). Jakarta: Penerbit Buku Kedokteran EGC.

Kaplan, H., Saddock, B., \& Grabb, J.(2010). Sinopsis Psikiatri Ilmu Pengetahuan Perilaku Psikiatri Klinis. Tangerang : Bina Rupa Aksara.

Keliat, B. A., \& Akemat. (2011). Model Praktek Keperawatan Profesional Jiwa. Jakarta: Penerbit Buku Kedokteran EGC

Lesmanawati, D. A. S. (2012). Analisis efektivitas biaya penggunaan terapi antipsikotika pada pasien skizofrenia di instalansi rawat inap RSJ Grhasia Yogyakarta. Karya Tulis Imiah strata dua, Universitas Gajah Mada,Yogyakarta.

Maramis, W.F., (2009). Retardasi Mental dalam Catatan Ilmu Kedokteran Jiwa Edisi kedua. Surabaya: pusat penerbitan dan percetakan UNAIR

Murray, R. K., Granner, D. K., \& Rodwell, V. W.Biokimia harper (27 ed.). Jakarta: Buku Kedokteran EGC; 2009

Notoatmodjo. (2014). Metodologi Penelitian Kesehatan.Jakarta: PT. Rineka Cipta.

Nursalam. (2013). Konsep Penerapan Metode Penelitian Ilmu Keperawatan. Jakarta: Salemba Medika.

Nursalam.(2015). Manajemen Keperawatan, Aplikasi dalam Praktek Keperawatan Profesional. Jakarta: Salemba Medika.

Reverger, M. J. (2012). Perbandingan performa fungsi pasien skizofrenia yang mendapat terapi tunggal dengan terapi kombinasi antipsikotika di Rumah Sakit Cipto Mangunkusumo. Karya Tulis Ilmiah strata dua, Universitas Indonesia, Jakarta.

Rineka Cipta, Notoatmodjo, S, 2005. Metodologi Penelitian Kesehatan. Jakarta: Rineka Cipta.

Harvard Health Publication, Havard Men's Health Watch (2007). Classification Blood Pressure

Hypertension Illinesses.United States, Boston.

Sadock \& Sadock, (2010). Ganggaun Pervasif dalam: Buku Ajar Psikiatri Klinis. Ed 2. Jakarta: EGC

Sekaran, Urna,1992. "Research Methods for Business". Third Edition. Southern Illionis University.

Semple, D., \& Smyth, R. (2013). Oxford Handbook of Psychiatry. Oxford: OxfordUniversity Press.

Sianturi, F. L. (2014). Risperidone and Haloperidol Comparative Effects of Positive Symptoms Patient Schizophrenic. Journal of Biology, Agriculture and Healthcare, Vol. 04 No. 28.

Stahl, S.M. (2013). Essential Psychopharmacology (4th ed.). Cambridge Cambridge University Press 
Swayami, I. G. A. V. (2014). Aspek Biologi Triheksifenidil di Bidang Psikiatri. Jurnal Ilmiah Kedokteran, 89-93.

Tan, H., \& Rahardja, K. (2015). Obat-Obat Penting. Edisi 7. Jakarta: PT Elex Media Komputindo.

Kementerian Kesehatan RI. (2013). Riset Kesehatan Dasar.Kemenkes RI.

Maslim, R. (2013). Buku Saku Diagnosis Gangguan Jiwa Rujukan Ringkas dari PPDGJ-III dan DSM-5. In Bagian Ilmu Kedokteran Jiwa FK-Unika Atmajaya.

Sugiyono. (2015). Metode Penelitian Kombinasi (Mix Methods). Alfabeta 